\title{
SOCIO-ECONOMICS OF HERBAL PROCESSING UNITS IN HIMACHAL PRADESH
}

\author{
Sukhjinder Singh, Sr. Technical Officer \\ C.S.I.R.- IHBT, Palampur, India \\ E-mail: sukhiinder.plp@gmail.com
}

\author{
Sharanjit Singh Dhillon, Professor of Economics \\ Guru Nanak Dev University, Amritsar (Punjab), India \\ E-mail: dhillon sharanjit@yahoo.co.in
}

\begin{abstract}
The study was designed to investigate the economics of herbal industrial units in Himachal Pradesh. Most of the herbal industries are organized as sole proprietorship followed by partnership, private, co-operative and private. Most of the entrepreneurs of herbal industrial units in H.P. were having experience 21 to 30 years. As an entrepreneur of herbal industry in H.P., Technical graduates (BAMS) were high in as compared to graduates other than BAMS. Profitability analysis revealed that herbal processing industry is a profitable venture. Multiple regression analysis showed that explanatory variables positively affecting the gross return of herbal industry of H.P. were found to be; expenses on packaging and qualification (number of years of schooling).
\end{abstract}

\section{KEY WORDS}

Herbal Industry, Socio-Economic Characters, Cost, Net Returns, Multiple Regressions.

The Ayurvedic industry in India is probably the oldest medical care system in the world. The history of herbs in ancient India is so old that the ancient form of herbal healing has even been mentioned in the Vedas. Even today, herbal medicines play a significant role in India. A similar practice is also prevalent in China, South East Asia and Africa. In a survey of 123 countries conducted by WHO in 2001 revealed that national recognition and regulation of Traditional medicine (TM) vary greatly amongst these countries. However there is increasing popularity of Traditional Medicine in the world due to its more affordability and proven efficacy in number of important health treatment areas. At global level, $80 \%$ population depends on traditional medicines for their primary health care need (Owolabi et al., 2007). The demand for plant based products are increasing in both developing and developed countries as they are generally considered as safe for consumption and use (Kalia, A.N., 2005).

The annual turnover of the Indian herbal industry is about Rs. 2,300 crore with a growth rate of $15 \%$ (Krishnan, R., 1998). Indian herbal market is likely to reach Rs.15, 000 crore by 2015 with a sustained growth (ASSOCHAM). Over the last three years USA, Pakistan, Germany, Japan, UK, Spain, China, France, Vietnam and Mexico were the top ten export destinations for India's herbal exports. USA is at the top with $35.7 \%$ of India's total herbal exports in 2009-10 followed by Pakistan constituting 10.6\%.

Due to having different agro-climatic zones, Himachal Pradesh is enriched with plant diversity. State Medicinal Plants Boards (SMPB), CSIR- IHBT, Other Government Research Bodies, Universities, NGOs, etc. are doing research for the purpose of promotional and commercial/ economic activity leading to cultivation and value addition of medicinal plants.

\section{METHODOLGY}

There are 95 Ayurvedic Pharmacies in the State, which are manufacturing herbal medicines after getting the license from the Department of Indian Systems of Medicine and Homeopathy (ISMH), Himachal Pradesh. 19 herbal units; 3 from Solan, 10 from Kangra, 3 from Paonta Sahib and 1 each from Bilaspur, Chamba and Una District were selected purposively. In accordance with the provision of Micro, Small \& Medium Enterprises Development (MSMED) Act, 2006; among all the herbal industries from the purposively 
sample selected industries for H.P., 4 under the category of small scale industrial category, whereas 15 fall under the category of micro industries.

The required primary data were collected through personal interview method with the help of a well structured and pre-tested schedule for the year 2012-13. The relevant basic information such as number of years of experience in herbal processing, qualification, type of ownership was collected. The data pertaining to investment pattern of the different units was also collected. The investment made on land, building, machinery \& equipments and tools etc. Cost components were calculated for the different items viz., raw material, electricity \& diesel, repair of building, causal and permanent labour, taxes paid etc. during the year 201213.

Cost components for herbal processing units have been divided into two categories (a) fixed cost and (b) variable cost. Fixed cost included depreciation of machinery and equipments, rental value of building and land, permanent labour and interest on fixed capital. Variable cost is the cost, which is incurred in subsequent years. It includes the cost on casual labour, raw materials used, chemicals, transportation charges, promotional charges, fuel, electricity, repair \& maintenance, packing material, audit and account charges, postage and stationary charges, medical and other expenses, taxes and interest on working capital.

Functional Analysis of Herbal Industries. The multiple regression technique was applied using three functional forms namely, linear, semilog and Cobb-Douglas. The best fit was selected after considering the levels of estimated error, magnitude of R2, number and signs of estimated regression coefficients. The Cobb-Douglas (CD) production function was used to study the resource use efficiency and influence of inputs on gross returns of herbal industrial units of both the states:

$$
\mathrm{Y}=\mathrm{a} \mathrm{X}_{1}^{\mathrm{b} 1} \mathrm{X}_{2}^{\mathrm{b} 2} \mathrm{X}_{3}^{\mathrm{b} 3} \ldots \ldots \ldots \ldots \mathrm{X}_{\mathrm{n}}^{\mathrm{bn}}+\mathrm{e}^{\mathrm{u}}
$$

The above function was converted into the linear form through logarithmic transformation of all variables and is written as:

$$
\log Y=\log a+b 1 \log X_{1}+b 2 \log X_{2}+b 3 \log X_{3}+\ldots \ldots \ldots \ldots \ldots+b n \log X n+u,
$$

where:

$\mathrm{Y}=$ Gross returns of Herbal Industry (Rs.)

$\mathrm{X}_{1}=$ Depreciation on Tools (Rs.)

$\mathrm{X}_{2}=$ Electricity Cost (Rs.)

$\mathrm{X}_{3}=$ Fuel Cost (Rs.)

$\mathrm{X}_{4}=$ Labour Cost (Rs.)

$\mathrm{X}_{5}=$ Packaging Cost (Rs.)

$\mathrm{X}_{6}=$ Cost of Raw Materail inputs (Rs.)

$\mathrm{X}_{7}=$ Processing Experience (years)

$\mathrm{X}_{8}=$ Education (years)

$\mathrm{U}=$ error term.

Descriptions, measurement and expected signs of variables:

Dependent Variable $(Y)$ : Gross returns of herbal industrial unit - The dependent variable $Y$ which represents the actual gross returns of herbal industrial unit by respondents, is a continuous random variable measured in Rupees.

Independent Variables $(\mathrm{X} i): \mathrm{X}_{1}=$ Depreciation on Tools $(\mathrm{N}), \mathrm{X}_{2}=$ Electricity Cost (Rs.), $\mathrm{X}_{3}=$ Fuel Cost (Rs.), $\mathrm{X}_{4}=$ Labour Cost (Rs.), $\mathrm{X}_{5}=$ Packaging Cost (Rs.), $\mathrm{X}_{6}=$ Cost of Raw Materail inputs (Rs.)- These variables are measured in terms of amount spent on depreciation of fixed items, electricity, fuel, labour used, packaging and raw material inputs respectively. They are measured in rupees and expected to have negative relationship with the net returns.

$\mathrm{X}_{7}=$ Processing Experience (years) - This indicated the number of years spent so far in processing business. According to Omoti (2001), the primary determinants of a potential 
processor's capabilities are experience in business and the quality of the information provided as far as extension workers are concerned. Based on their exposure it could be adjudged that they posses greater ability to predict possible problems and likely solutions that result in higher income. It is therefore expected that the farm experience will have a positive relationship with net returns.

$\mathrm{X}_{8}=$ Education (years) - This refers to the level of formal education received by the farmers. It is measured by the year of schooling. Educational level of the farmers is expected to have positive relationship with the net returns since educated farmers are more likely to be business alert and possess the ability to seize business initiatives or advantage.

\section{RESULTS AND DISCUSSIONS}

Socio-Economic Characteristics of the Sampled Herbal Units. It is necessary to look into the various socio-economic characteristics of sample herbal units before proceeding for analyzing a particular enterprise. Various socio-economic characteristics of sample respondents (herbal units) which include their organization and management, educational status of herbal entrepreneurs and experience of the enterprises in herbal processing are as below:

Organization and Management: the success of an industry depends on the entrepreneurs who manage it. It implies that the type of ownership and form of organization are important in an analysis of industrial performance of agro-processing units.

It was found during the survey that agro-processing industrial units in the study area are organized either as sole proprietorship or as partnership among family members or as partnership among non family members or as co-operative society or as charitable society or as private limited company. Distribution of units on the basis of the form of organization is given in Table 1. Surveyed herbal industrial units were organized $40.00 \%$ as sole proprietorship; $20.00 \%$ as partnership; $10.00 \%$ as co-operative; $15.00 \%$ as private; and $15.00 \%$ as government for herbal industry of H.P. respectively.

Most of the herbal industries are organized as sole proprietorship followed by partnership, private, government and co-operative.

Table 1 - Type of Ownership of herbal industries

\begin{tabular}{|l|l|}
\hline \multicolumn{1}{|c|}{ Type of ownership } & \multicolumn{1}{c|}{ in percent } \\
\hline Proprietary & 40.00 \\
\hline Partnership & 20.00 \\
\hline Co-operative & 10.00 \\
\hline Private & 15.00 \\
\hline Government & 15.00 \\
\hline
\end{tabular}

Experience of enterprises in processing herbs: years of experience in herbal processing also play an important role for the success of an enterprise. Years of experience were categorized into five categories i.e. 1 to 5 years, 6 to 10 years, 11 to 20 years, 21 to 30 years, 21 to 30 years and more than 30 years as depicted in Table 5.2. There were $5.26 \%$ herbal units having experience 1 to 5 years; 26.32\% herbal units having experience 6 to 10 years; $26.32 \%$ herbal units having experience 11 to 20 years; $31.58 \%$ herbal units having experience 21 to 30 years; and $10.53 \%$ herbal units having experience more than 30 years for H.P. as indicated in Table 2.

Table 2 - Experience of enterprises in herbal processing

\begin{tabular}{|l|l|}
\hline \multicolumn{1}{|c|}{ Experience (years) } & \multicolumn{1}{c|}{ in percent } \\
\hline 1 to5 & 5.26 \\
\hline 6 to 10 & 26.32 \\
\hline 11 to 20 & 26.32 \\
\hline 21 to 30 & 31.58 \\
\hline More than 30 & 10.53 \\
\hline
\end{tabular}


Education of Herbal Entrepreneurs: In order to analyze the educational levels of herbalprocessing entrepreneurs, they are categorized into two main categories, as technical (BAMS) and non- technical graduates (fields other than BAMS) in the respective field as given in Table 3. As an entrepreneur of herbal industry in H.P., Technical graduates (BAMS) were high in $(63.16 \%)$ as compared to graduates other than BAMS $(36.84 \%)$.

Table 3 - Education of Herbal Enterpreurs

\begin{tabular}{|l|l|}
\hline \multicolumn{1}{|c|}{ Qualification (years) } & \multicolumn{1}{c|}{ in percent } \\
\hline BAMS & 63.16 \\
\hline Other Graduate & 36.84 \\
\hline
\end{tabular}

Cost and Revenue Structure of Sampled Herbal Processing Units: different cost components (variable and fixed) and revenue structure of herbal industrial units of H.P. are indicated in Table 4. Building rent, depreciation of plant \& machinery, permanent labour and interest on fixed cost are major fixed cost components of small and micro herbal units of H.P. Percentage of total cost for different fixed components was evaluated. Depreciation on plant \& machinery was higher for small units of H.P. i.e. Rs. 2290214 (3.17 as percentage to TC) as compared to micro units for H.P. i.e. Rs. 68458 (1.41 as percentage to TC). Permanent labour charges were higher for small i.e Rs. 1158250.00 (1.60 as percentage to TC) as compared to micro herbal units of H.P. i.e. Rs. 326031 (6.74 as percentage to TC). Interest on fixed costs was higher for small herbal units i.e. Rs. 553502 (0.77 as percentage to TC) as compared to micro herbal units of H.P. i.e. Rs. 63349 (1.31 as percentage to TC). Rental value of building was also high for small units i.e. Rs. 588831 ( 0.81 as percentage to TC) as compared to micro herbal units of H.P. i.e. Rs. 44509 (0.92 as percentage to TC).

Table 4 - Costs involved in herbal processing units of H.P.

\begin{tabular}{|c|c|c|c|}
\hline SN & Particulars & Small & Micro \\
\hline A. & \multicolumn{3}{|l|}{ Fixed Cost (F.C.) } \\
\hline 1 & Insurance Premium & $90500(0.13)$ & $1000(0.02)$ \\
\hline 2 & Rental value of land & $36625(0.05)$ & $37361(0.77)$ \\
\hline 3 & Building rent & $588831(0.81)$ & $44509(0.92)$ \\
\hline 4 & Depreciation on Plant, Machinery and other equipments & $2290214(3.17)$ & $68458(1.41)$ \\
\hline 5 & License Fee & $12950(0.02)$ & $744(0.02)$ \\
\hline 6 & Permanent Labour charges & $1158250(1.60)$ & $326031(6.74)$ \\
\hline \multirow[t]{2}{*}{7} & Interest on FC @ 13.25\% & $553502(0.77)$ & $63349(1.31)$ \\
\hline & TFC $(7+8)$ & $4730872(6.54)$ & $541452(11.19)$ \\
\hline B. & \multicolumn{3}{|l|}{ Variable Cost (VC) } \\
\hline 1 & Raw Material & $24200000(33.45)$ & $1627740 \quad(33.63)$ \\
\hline 2 & Sugar & $3125000(4.32)$ & $74708(1.54)$ \\
\hline 3 & Chemicals \& preservatives & $2700000(3.73)$ & $30047(0.62)$ \\
\hline 5 & Electricity & $1340000(1.85)$ & $39636(0.82)$ \\
\hline 6 & Fuel & $575000(0.79)$ & $151745(3.14)$ \\
\hline 7 & Transportation charges & $2275000(3.14)$ & $51599(1.07)$ \\
\hline 8 & Repair \& Maintenance charges & $125000(0.17)$ & $16892(0.35)$ \\
\hline 9 & Labour Wages & $6876000(9.50)$ & $301736(6.23)$ \\
\hline 10 & Promotion charges & $75000(0.10)$ & $30623(0.63)$ \\
\hline 11 & Packing material & $14500000(20.04)$ & 1398123 (28.89) \\
\hline 12 & Audit \& account charges & $500000(0.69)$ & $38388(0.79)$ \\
\hline 13 & Postage \& Stationary & $286250(0.40)$ & $11501(0.24)$ \\
\hline 14 & Medical and other Expenditure & $255350(0.35)$ & $10869(0.22)$ \\
\hline 15 & Taxes & $3000000(4.15)$ & $20004(0.41)$ \\
\hline 16 & Interest on variable cost @ 13\% & $7778238(10.75)$ & $494469(10.22)$ \\
\hline 17 & Total Variable Cost (TVC) & $67610838(93.46)$ & $4298080(88.81)$ \\
\hline 18 & T.C. (TFC+TVC) & 72341710 & 4839532 \\
\hline 19 & Processing Cost & $10222375(14.13)$ & $569504(11.77)$ \\
\hline 20 & Gross returns (Sale) & 117500000 & 6057297 \\
\hline 21 & Returns over variable costs & 50487488 & 2253686 \\
\hline 22 & Net Returns & 45158290 & 1217765 \\
\hline
\end{tabular}

Figures in parenthesis indicates percentage to total cost. 
Total fixed cost was higher for small herbal units of H.P. i.e. Rs. $4730872(6.54$ as percentage to TC) as compared to micro herbal units of H.P. i.e. Rs. 541452 (11.19 as percentage to TC).

Raw material cost, cost of packing material, interest on variable cost and labour wages are major variable cost components. Variable cost and percentage of total cost for different variable cost components was evaluated. Raw material charges for small herbal units i.e. Rs. 24200000 (33.45 as percentage to TC) as compared to micro herbal units of H.P. i.e. Rs. 1627740 (33.63 as percentage to TC) were higher. Cost of packing material for small herbal units i.e. Rs. 14500000 (20.04 as percentage to TC) as compared to micro herbal units of H.P. i.e. Rs. 1398123 (28.89 as percentage to TC) were higher. Interest on total variable costs was higher for small herbal units i.e. Rs. 7778238 (10.75 as percentage to TC) as compared to micro herbal units of H.P. i.e. Rs. 494469 (10.22 as percentage to TC). Labour wages was higher for small herbal units of H.P. i.e. Rs. 6876000 (9.50 as percentage to TC) as compared to micro herbal units of H.P. i.e. Rs. 301736 (6.23 as percentage to TC). Total variable cost was higher for small herbal units i.e. Rs. 67610838 (93.46 as percentage to TC) as compared to micro herbal units of H.P. i.e. Rs. 4298080 (88.81 as percentage to TC). Processing cost was higher for small herbal units i.e. Rs. 10222375 (14.13 as percentage to TC) as compared to micro herbal units of H.P. i.e. Rs. 569504 (11.77 as percentage to TC).

Gross returns per small herbal unit (Rs. 117500000) was more than that of micro herbal unit (Rs. 6057297) of H.P. as depicted in Table 4.

Returns over variable costs of small herbal industrial units (Rs. 50487488) was more than micro herbal industries (Rs. 2253686) of H.P. Similarly, net returns of small herbal industries (Rs. 45158290) and micro herbal industries (Rs. 1217765) of H.P.

Multiple Regression Results of Sampled Herbal Industrial Units: the results of Multiple Regression of gross returns of Herbal Industry at H.P. are presented in Table 5. The F-ratio value was 29.328 , and was found to be statistically significant both at $5 \%$ and $1 \%$ level of significance, which imply that the model is adequate for use in further analysis. The coefficient of determination $\left(R^{2}\right)$ in case of herbal units was 0.967 , which implies that the independent variables explain at least $96.70 \%$ of the variability in gross returns of herbal industry in the study area of H.P.

Table 5 - Determinants of Gross Returns of Herbal Industry at H.P.

\begin{tabular}{|l|l|}
\hline \multicolumn{1}{|c|}{ Explanatory variables } & \multicolumn{1}{c|}{ Regression Coefficient } \\
\hline Intercept & $-17.819^{*}(7.068)$ \\
\hline Depreciation & $-0.0882(0.200)$ \\
\hline Electricity Cost & $0.413(0.231)$ \\
\hline Fuel Cost & $-0.0102(0.054)$ \\
\hline Labour Cost & $0.452(0.328)$ \\
\hline Packaging Cost & $0.758^{\star}(0.213)$ \\
\hline Raw material Cost & $-0.224(0.187)$ \\
\hline Experience & $0.289(0.275)$ \\
\hline Qualification & $14.022^{\star *}(6.227)$ \\
\hline Coefficient of multiple determination $\left(\mathrm{R}^{2}\right)$ & 0.967 \\
\hline Adjusted coefficient of multiple determination $\left(\mathrm{R}^{2}\right)$ & 0.934 \\
\hline \multicolumn{1}{|c}{$\mathrm{F}$} & 29.328 \\
\hline
\end{tabular}

The coefficient of packaging expenditure was found to be positive and significant at five per cent level of significance showing thereby that with increase in expenditure on packaging by one per cent the resultant gross return will increases by 0.758 per cent. The coefficients of qualification (years of schooling) of owner was also positively related to gross returns at one per cent level of significance. It shows that with increase in qualification of owner by one per cent, the resultant gross return increases by 14.002 per cent. The regression coefficients of other explanatory variables such as electricity, labour and experience were found to be positive but non-significant. The coefficient of depreciation cost, fuel cost and raw material input cost were found to be negative but non-significant. 
Therefore, the explanatory variables positively affecting the gross return of herbal industry of H.P. were found to be; expenses on packaging and qualification (number of years of schooling).

\section{CONCLUSION}

The present study was undertaken with a view to analyze the profitability as well as socio-economic characteristics of herbal industry in Himachal Pradesh. Most of the herbal industries are organized as sole proprietorship followed by partnership, private, co-operative and private. Most (31.58\%) of the entrepreneurs of herbal industrial units in H.P. were having experience 21 to 30 years. As an entrepreneur of herbal industry in H.P., Technical graduates (BAMS) were high in $(63.16 \%)$ as compared to graduates other than BAMS (36.84\%). Building rent, depreciation of plant \& machinery, permanent labour and interest on fixed cost are major fixed cost components; whereas raw material cost, cost of packing material, interest on variable cost and labour wages are major variable cost components of small and micro herbal units of H.P. Total variable cost constitute a major share (more than $80 \%$ ) of total cost for both small and micro herbal units. Returns over variable costs as well as net returns were higher for small as compared to micro herbal units. Explanatory variables positively affecting the gross return of herbal industry of H.P. were found to be; expenses on packaging and qualification (number of years of schooling).

\section{REFERENCES}

1. Owolabi .J Omogbai EKI, Obasuyi O (2007). Antifungal and antibacterial activities of the ethanolic and aqueous extract of Kigeliaafricana (Bignoniaceae) stem bark. African Journal of Biotechnology, 6 (14): 882-85.

2. Kalia, A.N. (2005). Text Book of Industrial Pharmacognosy. Oscar Publication

3. Krishnan, R., (1998). Indian Drug Manufactured Association Bulletin, 13: 318- 320

4. Department of Indian Systems of Medicine and Homeopathy (ISMH), Himachal Pradesh (2013). List of Ayurvedic Pharmacies in H.P. Retrieved from http://hpayurveda.nic.in/Insitutes_pvt_sec.htm

5. Omoti, U. (2001), "The future of the oil palm industry in Africa and strategies for Development, The Nigerian Situation". Paper prepared for the Africa Development Bank (ADB) workshop on the future oil oil palm industry in Africa and strategies for Development Cote D' Ivoire 